Evidence and Counter-Evidence, Festschrift Frederik Kortlandt, Volume 2 SSGL 33, Amsterdam - New York: Rodopi, 2008, 101-112

\title{
THE LANGUAGE ORGANISM: PARASITE OR MUTUALIST?
}

\author{
GEORGE VAN DRIEM
}

\begin{abstract}
'When I use a word,' Humpty Dumpty said, in rather a scornful tone, 'it means just what I choose it to mean - neither more nor less.' 'The question is,' said Alice, 'whether you can make words mean so many different things.' 'The question is,' said Humpty Dumpty, 'which is to be master - that's all.'
\end{abstract}

\section{Language is an organism}

The idea that language is a life form in its own right was popular amongst Indo-European linguists in Germany in the early 19th century. Friedrich von Schlegel described language as 'ein lebendiges Gewebe' (1808: 64), and Wilhelm von Humboldt spoke of the 'Organismus der Sprache' (1812: 8). Later, inspired by Ernst Haeckel's popularisation in Germany of Darwin's 1859 book On the Origin of Species, August Schleicher formulated a lucid statement on the organismal nature of language. Some have misinterpreted the conception of language as an organism as no more than a metaphor. Yet Schleicher's statement about language as a life form was unequivocally literal: 'Die Sprachen sind Naturorganismen, die, ohne vom Willen des Menschen bestimmbar zu sein, entstunden, nach bestimmten Gesetzen wuchsen und sich entwickelten und wiederum altern und absterben; auch ihnen ist jene Reihe von Erscheinungen eigen, die man unter dem Namen »Leben « zu verstehen pflegt' (1863: 6-7).

The conceptualisation of language as an organism remained popular, but the notion was reinterpreted by historical and comparative linguists in ways that differed from the intimations of more semiotically inclined thinkers. In retrospect, the thinking of the latter group blazed the trail for the Leiden school of language evolution. Victor Hugo wrote that 'le mot, qu' on le sache, est un Être vivant' (1856, I: 1. 675), and Gottlob Adolf Krause professed: 'Für mich ist jedes Wort ein sprechendes Lebewesen' (1885: 257). The indologist Max Müller and later the mathematician Bertus Brouwer had profound and often disturbing insights into the nature of linguistic meaning and the effects of language. Müller and Brouwer can be identified as Kortlandt's intellectual precursors. In the early 1980s, 
Kortlandt's tutorials led to the growth of the Leiden school of language evolution, with Jeroen Wiedenhof and myself as disciples. His now famous article on the language parasite, which appeared in 1985, explained that the nature of the organism stems from the fact that meanings are nonconstructible sets in the intuitionist mathematical sense. Kortlandt's view was a radical departure from earlier views on language as an organism, for his semiotic approach cut to the chase in identifying meaning and its behaviour as the crux of linguistics and language evolution.

In Kortlandt's Leiden school, the inherently dynamic character of meanings is seen as a direct function of their neuroanatomy, as modelled by Hebb (1949) and later elaborated by Changeux (1983) and Edelman (1987). Brouwerian semantics dovetails with neuroanatomical reality and the observable behaviour of categories of meaning as units in the Darwinian process of neuronal group selection. In the wake of Kortlandt's writings, i.e. $(1985,1998,2003)$, his Leiden students have begun to contribute to the discussion, e.g. Wiedenhof $(1996,1998,2000,2001 a, 2001 b$, 2002, 2003a, 2003b, 2003c, 2003d, 2004, this volume), van Driem (2000a, 2000b, 2001a, 2001b, 2003, 2004a, 2004b, 2005). Some critics have noticed that the Leiden school is not a single coherent view of language evolution, but three coherent views of language evolution, albeit largely congruent ones. This essay is an attempt to clarify a difference which some readers have perceived between Kortlandt's view of language and my own.

\section{Pessimistic vs. optimistic linguistics?}

The perceived difference between Kortlandt's view of language and my own has often been phrased, even by Kortlandt himself, along the lines of the master viewing language as a parasite, whereas his pupil sees language as a symbiont. Part of the confusion is terminological in nature, for technically a parasite too is a symbiont. Symbiosis is when two phylogenetically distinct organisms live together in some sort of intimate relationship. Symbiotic relationships abound in nature and take on many forms. The most far-reaching form of symbiosis is a relationship in which both organisms cannot live without the other and effectively become as one life form. Most life forms on the planet today originated as symbiotic relationships. An early understanding of the role of symbiosis in evolution dates back to the same period in the history of biology that evolution by natural selection first came to be understood by Charles Darwin and Alfred Russel Wallace.

Pierre Joseph van Beneden, professor at the Catholic University at Leuven, adopted the the term mutuellisme, brandished by the French social 
reformer Pierre-Joseph Proudhon for his ostensibly benign variety of communism, to apply to mutually beneficial relationships between species. The Belgian marine biologist later popularised the idea in his 1876 book Les commensaux et les parasites, which also appeared in German and English translations that same year. He distinguished various types of symbiotic relationship, i.e. parasite, free-living commensal, resident or obligate commensal and mutualist. Van Beneden stressed that beneficial reciprocity was as prevalent as commensalism. He described in detail how commensalism and mutualism contrasted strongly with the deleterious effects of parasitism and likewise carefully distinguished between various forms of commensalism and the intimate and reciprocally beneficial interdependency which characterised mutualism.

Van Beneden's work inspired the German botanist Heinrich Anton de Bary, who in 1879 popularised the word Symbiose 'symbiosis', an already extant term of Greek origin, in a public address to German biologists and physicians at Cassel as a cover term to designate all forms of 'Zusammenleben ungleichnamiger Organismen', i.e. the living together of organisms with different names, viz. belonging to differently named taxa. Symbiosis included 'der vollständige Parasitismus' (viz. full-fledged parasitism, which de Bary held to be the 'most exquisite' form of symbiosis), various types of commensals, and 'van Beneden's Mutualisten', which were neither parasitic nor commensal. De Bary's most fascinating examples were lichens. All lichens are symbiomes of fungi known as ascomycetes with either algae or cyanobacteria. His description of these fascinating symbiomes made lichens the emblematic classroom example of symbiosis.

Friedrich Schmitz, professor of botany in Bonn, observed that the chloroplasts of eukaryotic algae, along with their associated starchaccumulating structures called pyrenoids, were not fabricated anew in the cytoplasm, but reproduced independently by division within individual cells (1882). Schmitz first made this observation in 1880 'für eine Anzahl von Algen... während eines Aufenthaltes an der Zoologischen Station zu Neapel', but within two years he had established that the independent reproduction of Chromatophoren or chloroplasts was a feature of all eukaryotic algae. This observation regarding the autonomous nature of chloroplasts in eukaryotic algae inspired botanist Andreas Schimper, who in 1883 showed that Chlorophyllkörner or chloroplasts in green plants too 'nicht durch Neubildung aus dem Zellplasma, sondern durch Theilung aus einander entstehen' (1883: 106). This discovery led Schimper to venture that all green plants had originated through an original symbiotic association of two unlike organisms: 'Möglicherweise verdanken die grünen Pflanzen wirklich einer Vereinigung eines farblosen Organismus 
mit einem mit Chlorophyll gleichmäßig tingierten ihren Ursprung ${ }^{\prime}{ }^{1}$ In a similar vein, the botanist Albert Bernard Frank (1885) soon afterwards recognised mycorrhiza too to be a symbiotic relationship between terrestrial plants and subterranean fungi which subsist on their roots and provide these plants with essential nitrogen and minerals.

It was in Russia that the term symbiosis began to acquire a new anodyne flavour. Andrej Sergeevič Famintsyn studied the ontogeny of chloroplasts in green plants $(1889,1893,1907)$. His studies inspired Constantin Mereschkowksy to make the same observation in 1905 that Schmitz had made in 1880 and Schimper in 1883, namely that chloroplasts are not assembled from scratch in the cytoplasm, but are cytoplasmically inherited and replicate themselves autonomously within the host cell. Mereschkowksy went a step further than Schmitz and Schimper, however, in claiming that chloroplasts remained genetically independent of the nucleus. Mereschkowksy also argued that 'Cyanophyceae' or cyanobacteria, which until relatively recently used to be called blue-green algae, were basically free living chloroplasts that had not entered into the cytoplasma of a host cell, where they had taken up a reduced symbiotic existence and rendered the host cell autotrophic. For the genesis of a new life form through symbiosis, Mereschkowsky coined the term symbiogenesis in 1909.

Famintsyn felt that the term simbioz" should be reserved for relationships that were mutually beneficial, i.e. that simbioz" be used in the sense of van Beneden's mutualism rather than in the sense of de Bary's symbiosis. Famintsyn's symbiosis therefore excluded parasitism, which de Bary had considered to be the 'most exquisite' form of symbiosis. Since then, numerous types of symbiosis have been identified and analysed, and an elaborate terminology has evolved to designate different types of symbiotic relationship, e.g. parasymbiosis, social parasymbiosis, phoresy, inquilinism, symbiotrophism (Henry 1966, Margulis and Schwartz 1988). This rich arsenal of precise terminology contrasts with the feel-good 'New Age' flavour which the term symbiosis has acquired today in popular lay usage. Not all symbiotic relationships are mutually beneficial, but in lay parlance and even sometimes in biological discourse symbiosis is used to refer to mutually beneficial relationships. This connotation can be traced back to Famintsyn, who gave the term a favourable twist and thus set in

\footnotetext{
1 Recently, gene sequencing has provided the first genomic evidence that all plastids form a monophyletic group and that a single endosymbiotic event gave rise to a unified but highly diverse phylum comprising all primary photosynthetic eukaryotes, viz. green plants, red algae and glaucophytes (Rodríguez-Ezpeleta et al. 2005)
} 
motion a shift in meaning away from de Bary's original usage of Symbiose as a cover term for all forms of intimate inter-species relationship.

Recapitulating, the label 'Symbiotic Theory', which I introduced for the Leiden model of language evolution, can be applied to both Kortlandt's view of language and my own. Besides using the term symbiosis strictly in its original Flemish and German sense, i.e. free of value judgment, I have discussed the language organism whilst knowingly suggesting the originally Russian, now popular pleasant connotation of symbiosis as mutualism. Kortlandt, however, has insisted that language is a parasite. A terminologically more precise rephrasing of the difference between Kortlandt's view of language and mine, therefore, would be whether language is a parasite, and thus an organism deleterious to its hominid host, or a mutualist, and so a partner in a mutually beneficial symbiotic relationship. What I hope to show in the following section is that even this paraphrase represents an over-simplification of our views and of any real or perceived difference between them.

\section{The nature of the beast}

The beast in the brain is a complex organism in its own right and has a high degree of autonomy. We cannot change the grammatical structure of language or fundamentally change its lexicon by an act of will, even though we might be able to coin a new word or aid and abet the popularity of a turn of phrase. Language changes, but not because we want it to. We are inoculated with our native language in our infancy. Like any other life form, language consists of a self-replicating core. The units of this self-replicating core are the isofunctional neuronal correlates of signs in the sense of Ferdinand de Saussure, i.e. of meanings and of their associated phonological forms. So, is language a parasite or a mutualist? The architecture of language and the intricate dynamics of the relationship between the biological host and its memetic symbiont make the answer a complex one.

Our species has overrun the planet. A conventional measure of success for a species is reproductive fitness, and ours has manifestly been enhanced by language, whilst at the same time language thrives through us. By this criterion, therefore, language is a mutualist symbiont. If language were to be a parasite, then why has it not led to the extinction or at least attrition of our species? As Kortland thas darkly hinted in this context, time will tell. Moreover, he stresses that language is our own undoing even now, for throughout history and in each of our daily lives our most vexing problems derive from language. Language remains largely impervious 
to the well-being of man, and it colours and even stunts the perceptive faculties of its hominid host. Certainly, from the perspective of language, human brains are tools for the reproduction of language. Our grey matter has been recruited for the propagation of linguistic signs through the relentless proliferation from host to host of isofunctional neural constructs. The idea that language exerts an unfavourable effect on perception itself and blinds us to reality is an old idea already espoused by Bertus Brouwer and Frederik van Eeden. Language shapes our conceptual reality, yet there is a complex relationship between language as such and languageborne ideas. Whether or not the capricious nature of non-constructible sets portends our doom as a species, two other issues are relevant to an understanding of how the relationship between language and man straddles the distinction between mutualism vs. parasitism.

One issue is whether or not language actually debilitates its hominid host. We humans are inoculated with language at birth. Language infests our brain and stays with us until we are entirely brain-dead. Our brains teem with linguistic signs, and each time a linguistic form with its associated meaning is activated in our brain, a Darwinian generation time has elapsed in terms of the neuronal group selection which characterises the rapid life cycle of linguistic signs. By analogy with biological models, my contention has been that language itself is a mutualist, whereas not all meanings borne by language are mutualists. As in any symbiotic relationship, models predict that categories of meaning which are vertically transmitted from the parent host to his or her infant offspring are more likely to be mutualistic in nature. Such are the grammatical categories of a language and much of the core vocabulary which is structural to a given language. These constellations of meaning construct our reality and shape our perceptions in pervasive and insidious ways. Yet by and large the grammatical and lexical core of the language acquired in infancy collectively enhances the reproductive fitness of the hominid host.

By contrast, categories of meaning that are acquired subsequently and that are readily horizontally transmitted from host to host within a single host generation are less likely to be beneficial. Whereas some linguistic signs may be highly salubrious, others may be lethal to the host and devastating to the host community at large. Jihad, racial purity, proletariat, religious tenets and various brands of political correctness are obvious examples of pathological ideas, but in fact all horizontally transmitted thoughts are potentially dangerous and parasitic. We live the myths and ideas that impinge upon us and that wash across our societies. The distinction between the grammatical and lexical core of a language with which an infant human is inoculated and all the language-borne notions 
that the person acquires later in life is no sharp dichotomy but a fuzzy gradient. Applied to the language organism, the point of the distinction between the vertical and horizontal propagation of linguistic signs from host to host is merely that language-borne notions of reality such as infidel, Ahnenpaß or kosher will have a greater likelihood of being malevolent than meanings such as the present perfect tense, the zero morpheme for singular number in nouns, or lexical items such as mother, hungry and water. Meanings and syntactically articulated constellations of meanings may be wholesome, indifferent to the well-being of the host, or debilitating. This can only be judged by the effects of linguistic signs, certainly not by their appeal, which is no more than an index of their contagiousness and is no indication of their truthfulness.

The second issue is whether we are at the mercy of language. In his seminal article on the language parasite, Kortlandt stated: 'The view of language as a tool of the human species is less well-founded than its converse. The question is, in Humpty Dumpty's words, which is to be master' (1985: 478). I agree that we are at the mercy of language, but just who are we? Certainly, we are not just the hominid host, as the sad example of feral children teaches us (Ball 1880, Burnett 1784, de la Condamine 1755, Dresserus 1577, Itard 1801, 1894, Mason 1942, Singh and Zingg 1942, Sleeman 1858, Squires 1927, Rauber 1885). These soulless children are not fully human, though they are no doubt entirely hominid. We are not just flesh and blood, we are what we believe. We are symbiomes of body and soul. Our body is that of a particular variety of greater ape with all its social primate propensities, equipped with a brain which has grown bloated in a long process of coevolution with language. Our soul is the language organism which resides within our skull along with everything inside our brain that is mediated by language. The moment on the 5th of April 1887, when suddenly and heart-rendingly 'the mystery of language was revealed to' her, Helen Keller would subsequently describe as her 'soul's sudden awakening' (1905: 23). We are incomplete without language. The colonisation of an australopithecine brain by language was the symbiogenesis that yielded the first human beings.

The controversy about parasitism vs. mutualism boils down to the question of what makes us human. On the matter of our identity as a species, Wilhelm von Humboldt observed: 'Der Mensch ist nur Mensch durch Sprache' (1822: 244). The issue of whether the language organism or its hominid host has the upper hand begs the question of our very identity. When Humpty Dumpty asks who is to be master, how much does it really matter? If it feels good to live in a linguistically constructed reality, can this opium really be so bad for us? Of course, whenever we are 
driven to immolate ourselves for some abstract ideal, or to kill ourselves and murder others for the sake of some belief system, then this question becomes more pressing. We are as much our essentially linguistic soul as we are its corporeal hominid host. Being healthy involves keeping both components of a symbiome happy. Our brain houses a consciousness which sustains the illusion of a thinking self with a free will. In reality, our feelings, thoughts, yearnings and behaviour are the outcome of the jostle and interplay of the biological propensities and lust for creature comforts of the human host in symbiotic association with a capricious linguistic symbiont which serves as the vehicle for the ideas waging war within us. So when we speak, who is doing the talking?

Leiden University

\title{
REFERENCES
}

\author{
Ball, Valentine \\ 1880 Jungle Life in India, or the Journeys and Journals of an Indian Geologist. \\ London: T. de la Rue. \\ de Bary, Heinrich Anton \\ 1879 Die Erscheinung der Symbiose: Vortrag gehalten auf der Versammlung \\ Deutscher Naturforscher und Aerzte zu Cassel. Straßburg: Verlag von \\ Karl J. Trübner. \\ van Beneden, Pierre Joseph \\ 1876 Die Schmarotzer des Thierreichs. Leipzig: F.A. Brockhaus. \\ Burnett, James [Lord Monboddo] \\ 1784 Antient Metaphysics, Containing the History and Philosophy of Meng, Vol. III. \\ Edinburgh: J. Balfour. \\ Changeux, Jean-Pierre \\ 1983 L'homme neuronal. Paris: Librairie Arthème Fayard. \\ de la Condamine, Charles-Marie \\ 1755 Histoire d'une jeune fille sauvage, trouvée dans les bois à l'âge de dix ans. Paris: \\ Madame Hecquet. \\ Dresserus, Matthaeus \\ 1577 De Disciplina Nova et Veteri: Tam Domestica, quàm scholastica; Ad consolan- \\ dum erudiendumq[ue] parentes, praeceptores, ac liberos. Basel: Ex Officina \\ van Driem, George \\ Oporiniana. \\ 2000a "De evolutie van taal: Beginselen van de biologische taalwetenschap". \\ Public lecture delivered in Paradiso, Amsterdam, 16 April 2000. \\ $2000 \mathrm{~b} \quad$ "The language organism: A symbiotic theory of language". Paper pre- \\ sented at the Belgian-Dutch Workshop on the Evolution of Language \\ held at the Atomium in Brussels, 17 November 2000.
}


2001a Taal en Taalwetenschap. Leiden: Research School of Asian, African and Amerindian Studies CNWS.

2001b Languages of the Himalayas: An Ethnolinguistic Handbook of the Greater Himalayan Region with an Introduction to the Symbiotic Theory of Language (2 vols.). Leiden: Brill.

2003 "The Language Organism: The Leiden theory of language evolution". In: Jiří Mírovský, Anna Kotěšovcová and Eva Hajičová (eds.), Proceedings of the XVIIth International Congress of Linguists, Prague, July 24-29, 2003. Prague: Matfyzpress vydavatelství Matematicko-fyzikální fakulty Univerzity Karlovy.

2004a "Language as organism: A brief introduction to the Leiden theory of language evolution". In: Ying-chin Lin, Fang-min Hsu, Chun-chih Lee, Jackson T.-S. Sun, Hsiu-fang Yang and Dah-ah Ho (eds.), Studies on SinoTibetan Languages: Papers in Honor of Professor Hwang-cherng Gong on his Seventieth Birthday (Language and Linguistics Monograph Series W-4), 1-9. Taipei: Institute of Linguistics, Academia Sinica.

2004b "Het beest in ons brein: De Leidse taaltheorie". Public lecture for the NWO programme Bessensap: Wetenschap ontmoet pers, Amsterdam, 18 May 2004.

2005 "The language organism: The Leiden theory of language evolution". In: James W. Minett and William S-Y. Wang (eds.), Language Acquisition, Change and Emergence: Essays in Evolutionary Linguistics, 331-340. Hong Kong: City University of Hong Kong Press.

forthc. The Language Organism.

Edelman, Gerald M.

1987 Neural Darwinism: The Theory of Neuronal Group Selection. New York: Basic Books.

Famintsyn, Andrej Sergeevič

1889 "Beitrag zur Symbiose von Algen und Thieren". Mémoires de l'Académie Impériale des Sciences de St. Pétersbourg, XXXVI (16), 1-36.

1893 "O sud'bě zeren xlorofilla v semenax i prorostkax". Trudy Botaničeskoj Laboratorii Imperatorskoj Akademii Nauk 5, 1-16.

1907 "O roli simbioza v èvoljucii organizmov". Trudy Botaničeskoj Laboratorii Imperatorskoj Akademii Nauk 9, 1-14.

Frank, Albert Bernard

1885 "Ueber die auf Wurzelsymbiose beruhende Ernährung gewisser Bäume durch unterirdische Pilze". Berichte der Deutschen Botanischen Gesellschaft III, 128-145.

Hebb, Donald Olding

1949 The Organization of Behavior: A Neurophysiological Theory. New York: John Wiley \& Sons.

Henry, Sidney Mark

1966, 1967 Symbiosis (two vols.). New York and London: Academic Press.

Hugo, Victor

1856

Les contemplations (2 vols.). Bruxelles: Lebegue. 
von Humboldt, Wilhelm

1812 "Ankündigung einer Schrift über die vaskische Sprache und Nation, nebst Angabe des Gesichtpunctes und Inhalt derselben". In: F. Delbrück, C.G.A. Erfurdt, J.F. Herbart, K.D. Hülmann, J.F. Krause and J.S. Vater (eds.), Königsberger Archiv für Philosophie, Theologie, Sprachkunde unde Geschichte, 1-8 [i.e. eight numbered pages following p. 472]. Königsberg: Friedrich Nicolovius.

1822 "Ueber das vergleichende Sprachstudium in Beziehung auf die verschiedenen Epochen der Sprachentwicklung". Abhandlungen der Königlichen Preussischen Akademie der Wissenschaften, historisch-philosophische Klasse, aus den Jahren 1820 und 1821, 239-260.

Itard, Jean-Marc Gaspard

1801 [i.e. an X] De l'éducation d'un homme sauvage, ou Des premiers développements physiques et moraux du jeune sauvage de l'Aveyron. Paris: Goujon fils.

Itard, Jean-Marc-Gaspard

$1894 \quad$ Rapports et mémoires sur le sauvage de l'Aveyron, l'idiotie et la surdi-mutité. Paris: Félix Alcan. [posthumous]

Keller, Helen Adams

1905 The Story of My Life. New York: Doubleday, Page \& Company.

Kortlandt, Frederik Herman Henri

1985 "A parasitological view of non-constructible sets". In: Ursula Pieper and Gerhard Stickel (eds.), Studia linguistica diachronica et synchronica: Werner Winter sexagenario anno MCMLXXXIII gratis animis ab eius collegis, amicis discipulisque oblata, 477-483. Berlin: Mouton de Gruyter.

1998 "Syntax and semantics in the history of Chinese". Journal of Intercultural Studies 5, 167-176.

2003 "The origin and nature of the linguistic parasite". In: Brigitte Bauer and Georges-Jean Pinault (eds.), Language in Time and Space: A Festschrift for Werner Winter on the Occasion of his 80th Birthday, 241-244. Berlin: Mouton de Gruyter.

Krause, Gottlob Adolf

1885 "Die Stellung des Temne innerhalb der Bantu-Sprachen". Zeitschrift für afrikanische und oceanische Sprachen, mit besonderer Berücksichtigung der Deutschen Kolonien I, 250-267.

1998 Five Kingdoms: An Illustrated Guide to the Phyla of Life on Earth (third edition). New York: W.H. Freeman \& Company.

Mason, Marie K.

1942 "Learning to speak after six and one-half years of silence". Journal of Speech Disorders 7, 295-304.

Mereškovskij, Konstantin Sergeevič

1905 [Mereschkowsky, Constantin] "Über Natur und Ursprung der Chromatophoren im Pflanzenreiche". Biologisches Centralblatt XXV (18), 593604. 
1909a Teorija dvux plazm kak osnova simbiogenezisa, novogo učenija o proisxoždenii organizmov. Kazan': Tipografija Imperatorskago Kazan'skago Universiteta [published the same year in instalments in German translation as $(1909 b)]$.

1909b [Mereschkowsky, Constantin] “Theorie der zwei Plasmaarten als Grundlage der Symbiogenesis, einer neuen Lehre von der Entstehung der Organismen". Biologisches Centralblatt XXX (8), 278-288, XXX (9), 289303, XXX (10), 321-347, and XXX (11), 353-367.

Rauber, August

1885 Homo sapiens ferus, oder die Zustände der Verwilderten und ihre Bedeutung für Wissenschaft, Politik und Schule. Biologische Untersuchung von Dr. A. Rauber. Leipzig: Denicke.

Rodríguez-Ezpeleta, Naiara, Henner Brinkmann, Suzanne C. Burey, Béatrice Roure, Gertraud Burger, Wolfgang Löffelhardt, Hans J. Bohnert, Hervé Philippe and B. Franz Lang

2005 "Monophyly of primary photosynthetic eukaryotes: Green plants, red algae and glaucophytes". Current Biology 15, 1325-1330.

Schimper, Andreas Franz Wilhelm

1883 "Ueber die Entwickelung der Chlorophyllkörner und Farbkörper". Flora oder Allgemeine Botanische Zeitung, 41 (7), 105-114, 121-131, 137-146, 153162.

von Schlegel, Friedrich

$1808 \quad$ Ueber die Sprache und Weisheit der Indier: Ein Beitrag zur Begruendung der Alterthumskunde, nebst metrischen Uebersetzungen indischer Gedichte. Heidelberg: Mohr und Zimmer.

Schleicher, August

1863 Die Darwinsche Theorie und die Sprachwissenschaft: Offenes Sendschreiben an Herrn Dr. Ernst Häckel, a.o. Professor der Zoologie und Direktor des zoologischen Museums an der Universität Jena. Weimar: Böhlau.

Schmitz, Friedrich Karl Johann

1882 Die Chromatophoren der Algen. Vergleichende Untersuchungen über Bau und Entwicklung der Chlorophyllkörper und der analogen Farbstoffkörper der Algen. Bonn: Verlag von Max Cohen \& Sohn (Fr. Cohen).

Singh, Joseph Amrito Lal, and Robert M. Zingg

1942 Wolf Children and Feral Man. New York: Harper.

Sleeman, William Henry

1858 A Journey through the kingdom of Oude in 1849-1850 by Direction of the Right Honourable the Earl of Dalhousie, Governor-General, with Private Correspondence Relative to the Annexation of Oude to British India. London: $\mathrm{R}$. Bentley.

Squires, Paul

1927

"'Wolf children' of India". American Journal of Psychology 38, 313-315.

Wiedenhof, Jeroen Maarten

1996 "Nexus and the birth of syntax". Acta Linguistica Hafniensia 28, 139-150.

1998 "Over de oorsprong van taal". Interview in the radio programme Faros with Nelleke Rademaker, Radio 5 Teleac/NOT, 29 October 1998. 
"De oorsprong van taal”. Public lecture for the Studium Generale 'Universele geschiedenis van de big bang tot de last whimper', Leiden University, 28 March 2000.

2001a "De cognitieve wortels van de syntaxis". Public lecture in the series Vrijdagmiddaglezingen, Leiden University, 27 April 2001.

$2001 \mathrm{~b} \quad$ "Objects, situations and the syntactic revolution in early humans". Paper presented at the 7th International Cognitive Linguistics Conference, University of California at Santa Barbara, 27 July 2001.

2002 "Leidse visies op taal". Lecture for the Linguistics Student Union T.W.I.S.T., Leiden University, 17 October 2002.

2003a "De zin en onzin van taal". Public lecture delivered at Humanistisch Centrum Haaglanden, 's Gravenhage, 30 March 2003.

$2003 \mathrm{~b} \quad$ "Het fenomeen taal: Ontstaan, evolutie en gebruik". Lecture delivered at the Symposium VeRRassend Mind Express, Ghent University, 15 May 2003.

2003c "On the origins of linguistic meaning". Lecture delivered at the NWO Cognition Workshop: The Evolution of Meaning in a Game-Theoretical Setting, Koninklijke Nederlandse Akademie van Wetenschappen, het Trippenhuis, Amsterdam, 4 September 2003.

2003d "De oorsprong en evolutie van taal". Public lecture for the Studium

2004 "Taal en evolutie". Lecture delivered for the Stichting voor sociaal en cultureel werk De Boschkamp, Holten, 22 November 2004. 